VOLUME 13 NOMOR 2 TAHUN 2020

P-ISSN : 1979-9357

E-ISSN : 2620-5858

\title{
Model Pembelajaran Berbasis Literasi di Madrasah
}

\author{
Herman \\ Sekolah Tinggi Agama Islam Teungku Dirundeng Meulahoh \\ (herman@staindirundeng.ac.id)
}

\begin{abstract}
This article is aimed to describe the implementation of literacy-based learning model in fostering reading and writing interest, developing listening and speaking skill, and mastering information and technology. To these days, teachers seem to fail in constructing literacy-based learning model which lead to the weak culture and tradition of reading, listening and writing among the students, and the low skill in information and technology in this digital era of 4.0. The study was conducted in a qualitative approach employing library research method. Data collection was performed by reading relevant literature associated with the implementation of literacy-based learning model in Madrasah. The result of the study pointed that to implement literacy-based learning model can be performed through the following ways: 1) fostering reading interest, 2) developing writing interest and make it as a habit, 3) training and building up listening skill, 4) training and practising speaking skill, and 5) developing the ability and skill in information technology. The result of the study is recommended to madrasah headmasters and teachers so that they can implement a literacy-based learning model eagerly, accountably, and responsibly. Also, it is expected that they can work together with other stakeholders for the best implementation of the literacy-based learning model.
\end{abstract}

Keywords: Learning, Literacy, Model.

\begin{abstract}
Abstrak: Artikel ini bertujuan mendeskripsikan implementasikan model pembelajaran berbasis literasi dalam menumbuh kembangkan minat membaca, menulis dan melatih keterampilan menyimah, berbicara serta menguasai informasi dan teknologi. Selama ini guru gagal mengkonstruksikan proses pembelajaran berbasis literasi kepada peserta didik, sehingga berimbas lemahny a budaya literasi dikalangan peserta didik dalam menghadapi era digital, dan 4.0. Penelitian ini menggunakan pendekatan kualitatif dengan metode library research terhadap tulisan-tulisan yang berkaitan dengan topik yang dibahas. Kemudian teknik pengumpulan data dengan cara membaca berbagai literatur untuk mendeskripsikan tentang implementasikan model pembelajaran berbasis literasi di madrasah. Berdasarkan hasil pembahasan bahwa cara-cara mengimplementasikan model pembelajaran berbasis literasi dapat dilakukan sebagai berikut:1) menumbuh kembangkan minat membaca, 2) membangun minat, dan membiasakan menulis, 3) melatih, dan membina keterampilan menyimak, 4) melatih, dan membiasakan keterampilan berbicara, serta 5) mengembangkan kemampuan, dan kerampilan penguasaan informasi, dan teknologi. Hasil kajian ini dapat direkomendasikan kepada kepala madrasah, dan guru supaya dapat mengimplementasikan model pembelajaran berbasis literasi dengan sungguh-sungguh, amanah, dan tanggung jawab serta dapat bekerja sama dengan stakeholder lainnya demi terlaksana model pembelajaran berbasis literasi.
\end{abstract}

Kata kunci: Model, Pembelajaran, dan Literasi

\section{PENDAHULUAN}

Sepak terjang pendidikan Indonesia banyak menuai protes dari berbagai kalangan, terutama dikalangan akademisi, pemerhati pendidikan, dan stakeholder pendidikan lainnya terkait masalah kualitas pembelajaran. Guru gagal memproduksikan pembelajaran yang berkualitas, sehingga menghasilkan siswa kurang cerdas dan bermutu, serta kurang mampu dan terbuka pada saat berhadapan dengan realitaas sosial (social reality) sehingga mengalami kesulitan dalam mengikuti kemajuan informasi, dan teknologi era disruptive innovation. "Sebab kualitas peserta didik merupakan harga mati yang harus diproduksikan guru dalam proses pembelajaran di madrasah" (Muhammad Fadhli, 2016: 104).

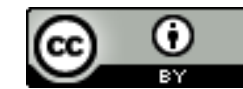

This work is licensed under a Creative Commons Attribution 4.0 International License 
VOLUME 13 NOMOR 2 TAHUN 2020

P-ISSN : 1979-9357

E-ISSN : $2620-5858$

Setiap lembaga pendidikan harus mendapatkan perhatian lebih terhadap mutu proses pembelajaran. Guru tidak boleh lengah dan lalai dalam mengkontruksikan proses pembelajaran kepada peserta dididk. Karena kegagalan dalam mengkontruksikan proses pembelajaran merupakan hal yang tidak diinginkan oleh stakeholder pendidikan, sebab kualitas pembelajaran merupakan ruh dari semua rangkaian kegiatan program pendidikan. Proses pembelajaran dapat dikemas dengan baik, dan konprehensif supaya hasil yang diproduksikan dari proses pembelajaran dapat melahirkan sumber daya manusia yang berkualitas. Proses pembelajaran yang baik bila selalu dilakukan disruption supaya dapat melahirkan siswa yang berkualitas. Siswa berkualitas merupakan hasil produksi dari proses pembelajaran berkualitas. "Proses pembelajaran berkualitas merupakan salah satu solutif yang ditawarkan di era disruption melalui implementasi model pembelajaran berbasis literasi" (Dirjen Dikdasmen, 2016: 1).

Pemerintah sudah banyak melakukan terobosan-terobosan terkait dengan hal itu, diantaranya melalui Peraturan Menteri Pendidikan, dan Kebudayaan (Pemendikbud) Nomor 23 Tahun 2015, tentang Penumbuhan Budi Pekerti. Dalam penumbuhan budi pekerti tersebut mengacu pada nilai-nilai kebangsaan, dan kemanusiaan, serta membiasakan siswa untuk membaca, dan menulis melalui kegiatan "Gerakan Literasi Sekolah (GLS)" (Menteri Pendidikan, dan Kebudayaan, 2015: 4). Permendiknas tersebut memberikan penguatan yang positif kepada guru dalam upaya meningkatkan kualitas proses pembelajaran melalui pengauatan literasi itu sendiri.

Gerakan Literasi Madrasah (GLM) merupakan sebuah upaya yang dilakukan secara menyeluruh untuk menjadikan madrasah sebagai organisasi pembelajaran yang berwarga literat sepanjang hayat melalui pelibatan publik. Upaya yang ditempuh berupa pembiasaan membaca, dan menulis para peserta didik. Ketika pembiasaan membaca, dan menulis terbentuk, selanjutnya akan diarahkan ke tahap pengembangan, dan peningkatan kualitas pembelajaran untuk mendukung pelaksanaan kurikulum 2013 yang mensyaratkan siswa membaca buku nonteks pelajaran (Dirjen Dikdasmen, 2016: 1).

Pembelajaran berkualitas adalah pembelajaran yang tidak hanya menyalurkan pengetahuan, dan keterampilan semata kepada peserta didik, melainkan melibatkan siswa secara totalitas dalam proses pembelajaran, baik di dalam kelas maupun di luar kelas. "Pembelajaran berkualitas dapat membangun literasi siswa terhadap pentingnya belajar, mengetahui cara belajar, dan cara memperoleh pengetahuan, dan keterampilan dari kegiatan belajar itu sendir" (Yunus Abidin, 2015: 13).

Guru sebagai fasilitator berkewajiban berperan aktif dalam melakukan Gerakan Literasi Madrasah (GLM) dengan cara memotivasikan. dan membiasakan siswa untuk membaca, dan menulis, serta mengembangkan kecakapan, dan keterampilan menyimak serta berbicara secara baik, dan benar dikalangan siswa (Dirjen Dikdasmen, 2016: 2) Siswa dapat melakukan sesuatu, dan mengaktualisasi diri didasarkan pada pemahaman membaca, dan menulis. "Membaca, dan menulis menjadi kebiasaan dan tradisi bagi peserta didik dalam kehidupan sehari-hari. 
VOLUME 13 NOMOR 2 TAHUN 2020

P-ISSN : 1979-9357

E-ISSN : $2620-5858$

Begitu juga menyimak dapat membuka wawasan, dan berbicara dapat menjadi lampu penerangan bagi semua pihak yang berhadapan dengannya" (I Made Ngurah, 2017: 156).

Pembelajaran berbasis literasi adalah pembelajaran yang menitik beratkan perhatian pada upaya-upaya memberikan motivasi, melatih, dan membiasakan siswa membaca, dan menulis, serta membina keterampilan menyimak, dan berbicara, serta keterampilan mengusai informasi, dan teknologi dalam kehidupan sehari-sehari. Semua variabel-variabel tersebut harus dilakukan disruption agar proses pembelajaran berbasis literasi menjadi sumber belajar guru, dan siswa dalam membangun jati diri di era digital, dan 4.0.

Masalah yang belum mampu terobati sampai sekarang ini adalah menyangkut guru gagal memproduksi model pembelajaran berbasis literasi, sehingga berimbas budaya membaca, dan menulis siswa menurun, serta penguasaan informasi, dan teknologi dikalangan siswa melemah. Dulu ketika buku sebagai satu-satunya sumber bacaan siswa, kenapa guru kurang mampu menjadikan siswa membaca, dan menulis sebagai kebutuhan hidupnya. Sekarang ketika dunia telah dikuasai oleh informasi, dan teknologi, guru juga kurang mampu menjadikan siswa memperoleh pengetahuan melalui membaca buku elektronik, dan mengakses informasi melalui media internet. Pada hal buku bisa didapat dimana-mana, dan pengetahuan bisa diakses kapanpun, dan dimanapun oleh siswa, tapi guru masih lengah, dan lalai menggiring siswa mengusai informasi, dan teknologi dalam kehidupan sehari-sehari.

Berdasarkan permasalan tersebut diatas, penulis ingin mengetahui bagaimana cara-cara mengimplementasi model pembelajaran berbasis literasi yang dapat mengantarkan siswa memiliki budaya membaca, dan menulis sampai pada tingkat menjadi kebutuhan dalam kehidupan sehari-hari, serta memiliki kecakapan, dan keterampilan dalam menyimak, dan berbicara pada saat berhadapan dengan orang lain dan mengusai informasi, dan teknologi pada saat berhadapan dengan realitas sosial. Melalui kajian tersebut diharapkan dapat membawa manfaaat bagi guru, dan siswa, serta stakeholdel lain dalam membudayakan literasi di lingkungan madrasah, dan masyarakat. Kemudian dapat menambah wawasan, dan pengalaman baru bagi pakar, dan pemerhati pendidikan dalam megembangan teori model pembejaran berbasis literasi dalam dunia pendidikan sekarang ini.

\section{METODE PENELITIAN}

Penelitian ini menggunakan metode library research dengan pendekatan kualitatif. Pengumpulan data menggunakan teknik membaca berbagai literatur yang berkaitan dengan implementasikan model pembelajaran berbasis literasi di madrasah (Nazir, 2003). Langkah-langkah yang ditempuh dalam penelitian ini, meliputi: pemilihan topik, eksplorasi informasi, menentukan fokus yang akan dibahas, pengumpulan sumber data, penyajian data, dan diiterprestasikan (Kuhlthau, 2002). Kemudian data tersebut dianalisis dan diinterprestasikan melalui buku-buku, literatur-literatur, catatan-catatan, artikel-artikel jurnal, dan 
VOLUME 13 NOMOR 2 TAHUN 2020

P-ISSN : 1979-9357

E-ISSN : $2620-5858$

peraturan perundang-undangan yang berlaku terkait dengan konsep pembelajaran, konsep literasi dan konsep implementasi model pembelajaran berbasis literasi di madrasah (Krippendoff, 1993).

\section{HASIL DAN PEMBAHASAN}

\section{Konsep Literasi Sekolah}

Istilah literasi berasal dari bahasa inggris, yaitu literacy dan dalam bahasa latin disebut literatu, yang artinya orang mencari ilmu. Kemudian dalam bahasa latin juga disebut dengan istilah litera (huruf) yang makna aturan tulisan dengan kesepakatan yang menyertainya. Menurut Unisco literasi merupakan seperangkat keterampilan nyata yang berkaitan dengan keterampilan kognitif membaca, dan menulis. Secara umum pengertian istilah literasi adalah kemampuan individu mengolah, dan memahami informasi saat membaca, dan menulis (https://www.literasipublik.com/pengertian-literasi, 2019). Selanjutnya istilah literasi terus berkembang makna baru pada abad ke 21, dimana kata literasi bukan saja dimaknai sebagai kemampuan membaca, dan menulis, akan tetapi sudah berkembang pengertian sampai pada berbagai bidang penting lainnya. Semua ini terjadi disebabkan pengaruh perkembangan zaman dari tradisional ke modern, dan dari zaman konfensional ke zaman digital (Yunus Abidin, dkk, 2017: 51).

Pembelajaran berbasis literasi lebih populer disebut sebagai pembelajaran mata pelajaran bahasa Indonesia, padahal dari segi kegunaan mencakup seluruh mata pelajaran yang diajarkan oleh guru oleh guru di madrasah. (Hendra Kurniawan, 2017: 1) Dilihat dari segi tradisional, literasi dipandang sebagai kemampuan membaca, dan menulis. Kemudian dalam perkembangan selanjutnya istilah literasi dimaknai tidak hanya sebatas sebagai kemampuan membaca, dan menulis, akan tetapi juga sdbagai keterampilan membaca, menyimak, menulis, dan berbicara (Yunus Abidin, dkk, 2017: 1).

\section{Komponen Literasi Sekolah}

Literasi secara luas bukan hanya sekedar membaca, dan menulis, tetapi mencakup keterampilan berpikir menggunakan sumber-sumber pengetahuan dalam berbagai bentuk media elektronik dan media cetak, visual, digital serta auditori. Pada abad ke 21 ini, kemampuan membaca, menyimak, dan menulis, serta berbicara disebut sebagai literasi informasi. Literasi informasi sekarang sudah menjadi kebutuhan primer bagi manusia. Manusia akan tergilas dalam kehidupannya, apabia tidak mengusai literasi informasi. Komponen literasi madrasah, meliputi: literasi dini, literasi dasar, literasi perpustakaan, literasi media, literasi teknologi, dan literasi visual. Untuk lebih jelas dari masing-masing komponen literasi madrasah dapat dijelaskan sebagai berikut (Dirjen Dikdasmen, 2016: 8-9):

a. Literasi dini

Literasi dini diartikan sebagai kemampuan untuk menyimak, memahami, dan kemampuan komunikasi melalui gambar, dan lisan yang dibentuk oleh pengalaman dan interaksi dengan lingkungan sosial dan di 
VOLUME 13 NOMOR 2 TAHUN 2020

P-ISSN : 1979-9357

E-ISSN : 2620-5858

rumah. Literasi dini sebagai pondasi awal dalam membangun literasi-literasi lainnya dalam proses pembelajaran di dalam dan di luar kelas.

b. Literasi dasar

Literasi dasar dipandang sebagai kemampuan untuk mendengarkan, berbicara, membaca, menulis, dan menghitung serta kemampuan analisis untuk memperhitungkan, mempersepsikan informasi, mengkomunikasikan serta menggambarkan informasi berdasarkan pemahaman, dan pengambilan kesimpulan pribadi.

c. Literasi perpustakaan

Literasi perpustakaan merupakan usaha memberikan pemahaman tentang tata cara melakukan dan membedakan antara bacaan fiksi, dan non fiksi serta tentang tata cara penggunaan dan pemahaman penggunaan katalog. Kemudian memberikan pengetahuan dalam memahami informasi ketika sedang menyelesaikan sebuah tulisan, penelitian, pekerjaan, atau mengatasi masalah. Literasi perpustakaan sebagai kunci sukses menggali informasi melalui mediamedia lain yang ada di perpustakaan.

d. Literasi media

Literasi media sebagai wujud memiliki kemampuan untuk mengetahui berbagai bentuk media yang ada, seperti media cetak, media elektronik (media radio, dan media televise), media zoom dan virtual dan kemampuan memahami tujuan penggunaan media tersebut. Semua jenis media tersebut harus dijadikan sebagai perangkat kerja pada saat menggali berbagai sumber pengetahuan yang dibutuhkannya dalam kehidupan sehari-sehari.

e. Literasi teknologi

Literasi teknologi dapat diartikan sebagai kemampuan memahami komponen-komponen teknologi secara konprehensif dan meningkatkan kelancaran kerja melalui pemanfaatan teknologi dalam berkarya dan bekerja, seperti perangkat keras, perangkat lunak, serta etika dalam memanfaatkan teknologi. Kemudian semakin cerdas dan terampil penggunaan tenologi, maka semakin meningkatkan daya saing dan prestasi kerja dalam hidupnya.

f. Literasi visual

Literasi visual merupakan wujut penalaran tingkat tinggi literasi media, dan literasi teknologi dalam membangkitkan penalaran dan kondisi belajar yang efektif dalam mengembangkan penalaran apa yang terkandung dan terlihat dalam visual, dan audio visual. Literasi visual dapat mengaktifkan panca indra dalam menggali, dan mengembangkan informasi secara intensif untuk menghasilkan pengetahuan, keterampilan, dan menemukan jati dirinya.

\section{Kerangka Konsepsional Model Pembelajaran Berbasis Literasi}

Beranjak dari konsep literasi, maka kerangka konseptual model pembelajaran berbasis literasi, dapat didesain melalui 5 (lima) konsep adalah sebagai berikut: 1) menumbuh kembangkan minat membaca siswa, 2) membangkitkan minat, dan membiasakan menulis siswa, 3) melatih, dan membina keterampilan menyimak siswa, 4) melatih, dan membiasakan keterampilan 


\section{AT-TAFRIR}

VOLUME 13 NOMOR 2 TAHUN 2020

P-ISSN : 1979-9357

E-ISSN : 2620-5858

berbicara siswa, dan 5) mengembangkan kemampuan, dan keterampilan menguasai informasi, dan teknologi di era disrupsi.

Skema desain model pembelajaran berbasis literasi adalah sebagai berikut:

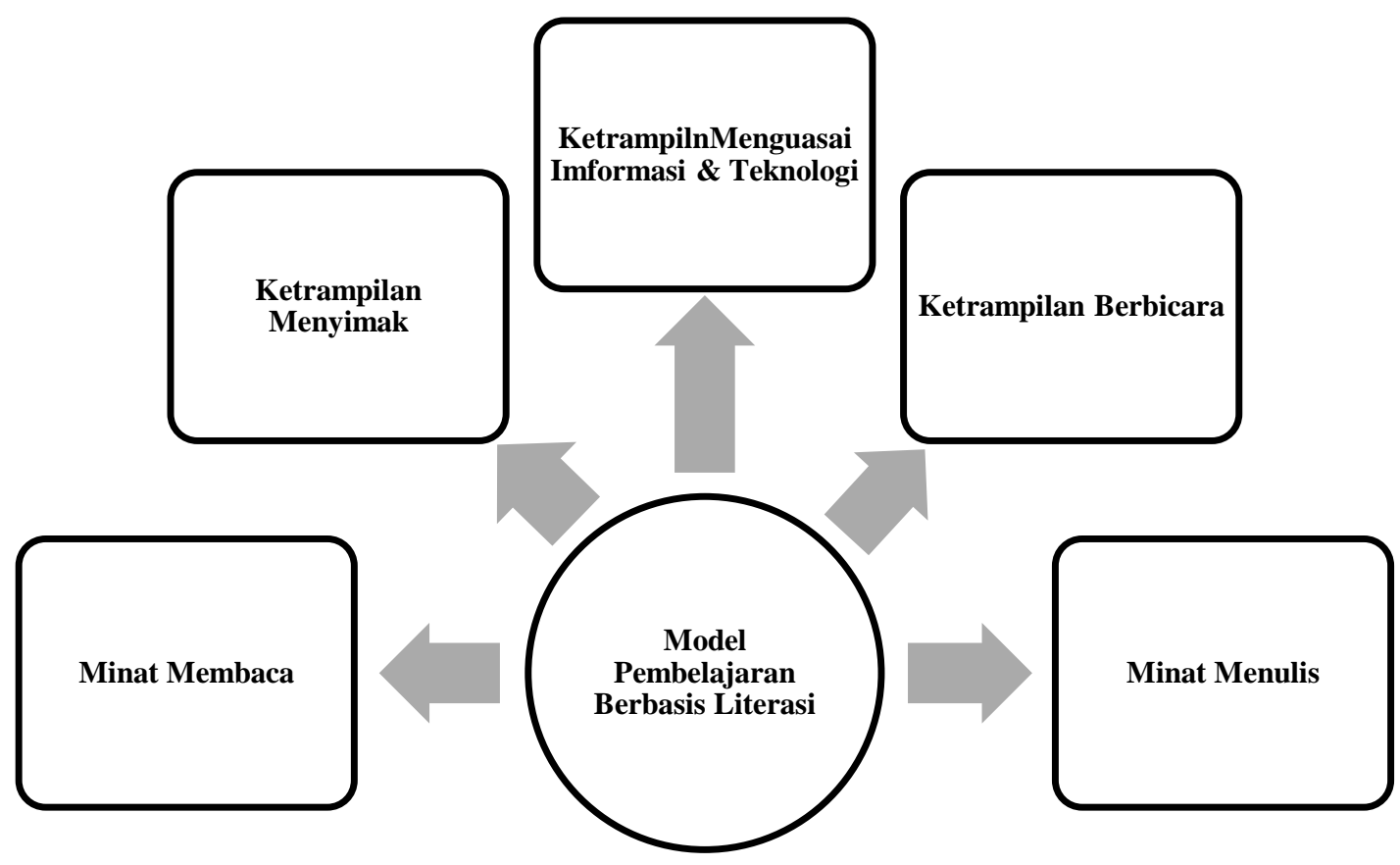

Gambar: Desain Model Pembelajaran Berbasis Literasi

Kelima konsepsional tersebut sebagai prinsip dasar, dan menjadi kekuatan moral dalam proses pembelajaran berbasis literasi, dan kelima konsep tersebut saling menunjang satu sama lainnya dalam mengkontruksikan proses pembelajaran berbasis literasi di dalam, dan di luar kelas.

\section{Implementasi Model Pembelajaran Berbasis Literasi}

Dalam mengimplementasikan model pembelajaran berbasis literasi, seorang guru harus mampu mengembangkan kecakapan hidup (life skills) melalui membangun, dan mengembangkan budaya, dan tradisi literasi dikalangan siswa. Model pembelajaran berbasis literasi dapat menggiring siswa agar tumbuh minat membaca, dan menulis, serta keterampilan menyimak, dan berbicara, serta dapat menguasai informasi, dan teknologi di era digital.

1. Menumbuh Kembangkan Minat Membaca

Dalam menumbuh kembangkan minat membaca dalam konsep literasi, membaca merupakan sebuah usaha untuk memahami, menggunakan, merefleksikan, dan dalam mempraktekkan dalam berbagai jenis teks untuk mencapai tujuan (Yunus Abidin, dkk, 2017:165). Membaca dapat berfungsi 
VOLUME 13 NOMOR 2 TAHUN 2020

P-ISSN : 1979-9357

E-ISSN : $2620-5858$

sebagai sarana memperoleh ilmu pengetahuan. Membaca membutuhkan keterampilan untuk memahami informasi secara analitis, kritis, dan reflektif (Hendra Kurniawan, 2017: 5). Kegiatan membaca tetap dimulai dengan memaknai teks, mendiskusikan teks, dan membangun pemahaman terhadap isi teks. Kemudian baru berusaha untuk menyimpul, mengevaluasi, dan mengkonfirmasi hasil bacaan tersebut (Hendra Kurniawan, 2017: 10-11).

Membangun, dan menumbuh kembangkan minat membaca para siswa bukanlah hal mudah, dan gampang bagi seorang guru, karena siswa memiliki karakter yang berbeda satu sama lainnya. Guru sebagai motivator harus mampu mengkonstruksikan minat membaca siswa sampai pada ke tingkat menjadi kebutuhan bagi mareka. Kalau minat membaca sudah menjadi kebutuhan, maka akan melahirkan daya tarik untuk membaca teks, dan memaknai teks, mendiskusi teks, dan membangun pemahaman teks secara komprehensif, objektif, dan sepenuh hati. Dalam mengkonstruksikan pembelajaran berbasis literasi, guru sebagai fasilitator dapat memberikan kesempatan kepada siswa untuk dapat membaca teks, dan memaknai teks secara termotivasi, dan sungguh-sungguh. Minat membaca, dan memaknai teks muncul karena adanya perhatian, dan insentif (imbalan) yang distimuluskan guru dalam proses pembelajaran. Karena perhatian yang tinggi terhadap membaca, dan memaknai teks dengan serius, dan sungguh-sungguh siswa dapat menggali informasi dengan kreatif, dan aktif, serta mendalam terhadap apa yang sedang dipelajarinya (Slameto, 2010: 121).

\section{Melatih, dan Membina Keterampilan Menyimak}

Menyimak dimaknai bukan hanya sekedar kegiatan mendengar semata, melainkan mengcakup menggali, dan memahami informasi berbagai informasi. Kegiatan menyimak berfungsi sebagai wadah untuk memperluas wawasan, dan pengetahuan, serta bagaimana cara-cara untuk mendapat informasi tersebut. "Keterampilan membaca, dan menyimak sifatnya saling menopang, dan melengkapi untuk memperoleh pemahaman literasi secara mendalam, dan komprehensif" (Hendra Kurniawan, 2017: 12).

Guru yang profesionalkan adalah guru yang mampu melakukan conditioning terhadap siswa supaya mau menyimak, dan mengikuti interaksi pembelajaran secara baik, dan benar. Siswa diconditioningkan termotivasi menyimak dengan hati yang senang, dan pikiran yang terbuka, serta luwes terhadap sumber literasi yang sedang dikaji, dan bahas dalam proses pembelajaran. Semua teks yang dipelajari dapat dipahami secara detil, dan komprehensif sehingga hasil kajian tersebut betul-betul menjadi bagian dari sikap, dan perilakunya.

Melatih, dan membina keterampilan menyimak siswa harus sampai pada tingkat menimbulkan kesadaran, dan kenyakinan pada diri siswa bahwa apa yang sedang dibaca, dan dimaknainya menjadi pengetahuan dan keterampilan untuk memenuhi harapan hidupnya, dan dapat merobah tingkah laku kearah yang lebih baik. "Karena kegiatan menyimak adalah membangun 
VOLUME 13 NOMOR 2 TAHUN 2020

P-ISSN : 1979-9357

E-ISSN : 2620-5858

gagasan atau pemahaman sendiri, dan menimbulkan motif untuk melakukan sesuatu yang terbaik untuk dirinya, dan orang lain" (W.S. Winkel SJ, 1996: 53).

\section{Membangkitkan minat, dan Membiasakan Menulis}

Menulis merupakan rangkaian kegiatan membangun makna dari sebuah gagasan atas dasar pengetahuan yang dimikinya (W.S. Winkel SJ, 1996: 53). Menulis disebut juga menyalurkan ide kepada orang lain, dan memberikan pemahaman atas sesuatu hal yang sedang dipelajari, dan dikajinya. Melalui kegiatan menulis, siswa akan mampu mengkomunikasikan ide-ide tersebut pada orang lain sehingga akan terbina kemampuan dalam berkomunikasi, dan mudah bekerja sama dengan pihak lainnya.

Guru sebagai fasilitator tidak pernah lengah dan lesu dalam membangkitkan minat siswa untuk menulis terhadap apa yang sedang ia pelajarinya, serta dapat memotivasi siswa dimana saja, dan kapan saja yang penting siswa dapat menulisnya. Siswa senang hati menulis makalah, jurnal, buku, dan karya ilmiahnya. Ia terus mengajari siswa menulis secara baik, dan benar sesuai menurut ketentuan karya ilmiah. Kemudian melatih siswa untuk bisa merumuskan pendahuluan, landasan teori, pembahasan, dan penutup sesuai dengan kaedah karya ilmiah.

Kemudian ia terus menumbuh kembangkan budaya, dan tradisi menulis di lingkungan madrasah, dan masyarakat. Ia terus mengingat siswa bahwa setiap ide, dan gagasan yang muncul dalam dirinya dapat ditulis sesuai menurut kaedah karya ilmiah. Ia menggiring siswa supaya tertarik, dan termotivasi untuk menulisnya. Ia menggerakkan siswa supaya tidak berpaku tangan, dan berleha-berleha sehingga hilang kesempatan untuk menulisnya. Kemudian ia sangat bangga terhadap hasil karya ilmiah yang ditulis oleh siswa, dan menyuruh siswa untuk mempublikasikan pada media cetak, dan media online.

\section{Melatih, dan Membiasakan Berbicara}

Keterampilan berbicara merupakan kemampuan memproduksikan gagasan secara lisan supaya melahirkan ide-ide yang berkualitas dan tata cara penyampaian yang tepat sasaran dan mengandung nilai etika. Mengolah isi pembicaraan dapat diterima oleh semua kalangan dengan hati yang terbuka, baik dari segi idenya maupun cara menyampaikan pesannya. Isinya dapat meyakinkan orang lain, dan meyakini kebenarannya. "Skill dalam mengungkapkan argumen merupakan karakteristik seseorang memiliki pengetahuan yang luas, kemampuan berpikir kritis, kreatif, dan inovatif serta matang, dan dewasa untuk beradaptasi dengan orang lain (Yunus Abidin, dkk, 2017: 63).

Guru sebagai demontran dalam proses pembelajaran harus mampu melatih siswa supaya terampil dalam berbicara di depan kelas, maupun di hadapan khalayak ramai. Siswa dapat dengan mudah mengutarakan ide, dan gagasan dengan sopan dan santun. Tutur bahasa yang indah diutarakan, tersusun rapi, ilmiah, respek, valid, dan konprehefsif. Semua ide, dan gagasan 
VOLUME 13 NOMOR 2 TAHUN 2020

P-ISSN : 1979-9357

E-ISSN : $2620-5858$

dapat tersalurkan dengan baik, bermanfaat, bermartabat, dan mudah dipahami serta dimengerti oleh semua orang, tidak emosi, dan tidak suka menjatuhkan wibawa, dan gedhah orang lain.

Guru profesional dalam mengkonstruksikan proses pembelajaran selalu membiasakan diri siswa supaya bisa berbicara sesuai dengan kaedah bahasa yang benar, beretika, dan selalu sesuai dengan adat istiadat setempat. Nada yang disampai adalah lembut, sopan, dan ramah dalam setiap berinteraksi dengan orang lain. Semua itu menjadi kebiasaan dalam setiap even beradaptasi dengan orang lain.

\section{Mengembangkan Kemampuan, dan Keterampilan Menguasai Informasi,} dan Teknologi

Kemajuan teknologi internet telah mengantar individu lebih maju, dan progresif dalam menghadapi kemajuan zaman. Kemajuan zaman teknologi dan informasi sudah menjadi kebutuhan yang sangat urgen dalam kehidupan manusia, bahkan bisa membuat manusia digilas oleh zaman dalam meniti hidupnya. Bagi pelaku usaha, informasi bisa dianggap sebagai senjata modal meningkatkan hasil usahanya. Bagi militer, informasi bisa dianggap sebagai modal mengatur strategi perang melawan musuk, dan bagi para wartawan, informasi bisa dijadikan sebagai modal menaikkan power media cetak dan elektroniknya (Rifkie Primartha, 2018: 371). Begitu juga bagi guru, informasi menjadi senjata untuk melakukan perubahan dan pembaruan kedepan. Kemudian bagi siswa, informasi bisa menjadi sarana menguasai dunia.

Mengingat begitu berharganya suatu informasi, maka guru harus menguasai informasi setiap saat, dan waktu. Guru harus melek dengan teknologi supaya materi yang disajikan tidak ketinggalan zaman, uptudate, dan berinovasi. Guru harus banyak mengakses informasi lewat internet, membaca buku, jurnal dan karya tulis ilmiah, supaya kaya dengan berbagai informasi. Guru yang sukses adalah guru kaya dengan informasi, indah akhlaknya, dan terampil dalam bertindak dan berbuat dalam proses pembelajaran.

Dalam proses pembelajaran, guru bukan zamannya lagi mengajar secara manual, dan tradisional, akan tetapi harus cerdas menggunakan power point, menggunakan word dengan mudah, dan mahir, dan menggunakan rumus, grafik, dan tabel dengan aplikasi excel, serta mampu meng-upload materi/bahan ajar ke dalam sistem. Sebelum mengajar ia telah membuat mindmapping-nya terlebih dahulu. Kemudian mengajar tidak hanya dengan metode ceramah, menggunakan LKS, dan penugasan semata, akan tetapi ia terus melakukan inovasi, dan disruption dalam proses pembelajarannya.

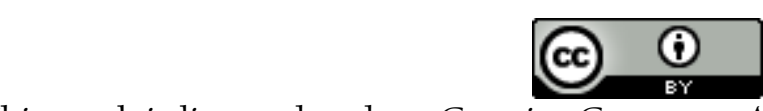

This work is licensed under a Creative Commons Attribution 4.0 International License 
VOLUME 13 NOMOR 2 TAHUN 2020

P-ISSN : 1979-9357

E-ISSN : 2620-5858

\section{KESIMPULAN}

Berdasarkan kajian pembahasan diatas dapat disimpulkan bahwa cara mengimplementasikan model pembelajaran berbasis literasi dapat dilakukan dengan cara menumbuh kembangkan minat membaca, membangkitkan minat, dan membiasakan menulis, melatih, dan membina keterampilan menyimak, melatih, dan membiasakan keterampilan berbicara serta mengembangkan kemampuan, kerampilan menguasai informasi, dan teknologi. Kemudian hasil kajian tersebut dapat direkomendasikan kepada kepala madrasah, dan guru supaya dapat mengimplementasikan model pembelajaran berbasis literasi dengan sungguhsungguh, amanah, dan tanggung jawab serta dapat bekerja sama dengan stakeholder lainnya demi terlaksana model pembelajaran berbasis literasi di madrasah.

\section{DAFTAR PUSTAKA}

Dirjen Dikdasmen, Panduan Gerakan Literasi Sekolah: di Sekolah Menengah Atas, (Jakarta: Kemendikbud, 2016)

Dirjen Dikdasmen, Desain Induk Gerakan Literasi Sekolah, (Jakarta: Kemendikbud, 2016)

Hendra Kurniawan, "Pembelajaran Literasi dalam Mata Pelajaran Sejarah", (Histori Vitae, Vol. 32, No. 1, Universitas Sanata Dharma)

https://www.literasipublik.com/pengertian-literasi, diakses tanggal 18 Desember 2019

I Made Ngurah, Mendidik Lewat Literasi Untuk Pendidikan Berkualitas, (Jurnal Penjamin Mutu Institut Hindu Dharma Negeri Denpasar, Volume 3, Nomor 2, 2017)

Yunus Abidin, Pembelajaran Multiliterasi, (Bandung: PT Refika Aditama, 2015)

Yunus Abidin, dkk, Pembelajaran Literasi: Strategi Meningkatkan Kemampuan Literasi Matematika, Sains, Membaca, dan Menulis, (Jakarta: Bumi Aksara, 2017)

Muhammad Fadhli, Manajemen Peningkatan Mutu Pendidikan, (Jurnal Itqan, Vol. VII, No. 1, Ja nuari - Juni 2016)

Menteri Pendidikan, dan Kebudayaan, Peraturan Menteri Pendidikan dan Kebudayaan Republik Indonesia, Nomor 23 Tahun 2015, Tentang Penumbuhan Budi Pekerti, (Jakarta: Kemendikbud, 2015)

Rifkie Primartha, Penerapan Enkripsi dan Dekripsi File Menggunakan Algoritma Data Encryption, (Jurnal Sistem Informasi (JSI), Vol. 3, No.2, 201l, ISSN Print: 2085-1588, ISSN Online: 2355-4614)

Slameto, Belajar dan Faktor-faktor Yang Mempengaruhinya, (Jakarta: Rene Cipta, 2010), W.S. Winkel SJ, Psikologi Pengajaran, (Jakarta: Grasindo, 1996) 